\title{
APLIKASI MODEL PERSEDIAAN PROBABILISTIK Q DENGAN PERTIMBANGAN LOST SALES PADA APOTEK X
}

\author{
Steaven Leonardo Chandra, Theresia Sunarni \\ Program Studi Teknik Industri Universitas Katolik Musi Charitas \\ e-mail: steavenleonardo98@gmail.com,t_sunarni@ukmc.ac.id
}

\begin{abstract}
ABSTRAK
Pengendalian persediaan obat-obatan bertujuan agar apotek dapat memenuhi seluruh permintaan konsumen sehingga kemungkinan untuk terjadinya kasus lost sales dapat diminimalisir. Permintaan obat yang tidak dapat dipenuhi dapat menyebabkan ketidakpuasan konsumen dan akan berdampak pada nama baik apotek sebagai suatu perusahaan dagang. Penelitian ini dilakukan untuk memperbaiki sistem pengendalian persediaan pada Apotek X, sehingga dapat meminimalisir terjadinya kasus lost sales yang diakibatkan oleh permintaan obat yang fluktuatif dan tidak menentu. Penelitian ini menggunakan obat-obatan jenis paten sebagai objek penelitian. Pada penelitian ini, seluruh jenis obat-obatan paten dibagi ke dalam tiga kelompok dengan kelompok A menyerap biaya investasi sebesar 70,21\%, kelompok B menyerap biaya investasi sebesar 19,98\% dan kelompok C menyerap biaya investasi sebesar 9,81\%. Pengelompokkan dengan metode klasifikasi ABC dilakukan agar petugas apotek dapat memprioritaskan dan mengawasi persediaan obat pada kelompok A secara lebih ketat karena kelompok obat ini menghabiskan biaya investasi paling tinggi. Hasil penelitian ini berupa perhitungan kuantitas pemesanan dan juga reorder point dengan model persediaan probabilistik $Q$ Lost Sales yang digunakan sebagai masukan dalam menjalankan two bin system. Dengan menggunakan two bin system, maka terjadi peningkatan rata-rata persentase pemenuhan penjualan sebesar 23,78 persen dan menghemat biaya persediaan sebesar 31,79 persen.
\end{abstract}

Kata kunci: Pengendalian Persediaan, Klasifikasi ABC, Q Lost Sales, Sistem Dua Bin, Total Biaya Persediaan.

\begin{abstract}
Drug inventory control aims so that pharmacist can fullfill all consumer demand so that the possibility of lost sales can be minimized. Drug demand that cannot be fulfilled will affect on consumer dissatisfaction and will have an impact on reputation of the pharmacy as a trading company. This research was conducted to improve the inventory control system at X Pharmacy so as to minimize the case of lost sales caused by fluctuating and uncertain drug demand. This study uses patent type medicines as the research objects. In this study, all types of patent medicines were divided into three groups with group A absorbing investment costs by 70,21\%, group B absorbing investment costs by $19,98 \%$ and group $C$ absorbing investment costs by 9,81\%. Grouping by the ABC classification method is done so that pharmacist can prioritize and supervise the supply of drugs in group A more accuratetly because these drug groups spend the highest investment costs. The results of this study are the calculation of the order quantity and also the reorder point with the $Q$ Lost Sales probabilistic inventory model which is used as an input to run the two bin system. By using the two bin system, an increase in the average percentage of fulfillment of sales by 23,78 percent and saving inventory costs by 31,79 percent.
\end{abstract}

Keywords: Inventory Control, ABC Classification, $Q$ Lost Sales, Two Bin System , Total Inventory Cost.

\section{PENDAHULUAN}

Persediaan merupakan salah satu aset penting dalam perusahaan karena mempunyai nilai yang cukup besar dan mempunyai pengaruh terhadap total biaya operasi sehingga perencanaan dan pengendalian persediaan merupakan salah satu kegiatan yang harus mendapatkan perhatian khusus dari manajemen perusahaan [1]. Persediaan yang terlalu besar (over stock) merupakan suatu pemborosan karena barang tersebut tidak habis terjual dan tentunya akan menyebabkan modal usaha menjadi tidak berputar. Di samping itu, persediaan barang yang terlalu sedikit juga akan menimbulkan masalah karena dapat 
menimbulkan kekurangan persediaan (out of stock) sehingga dapat menganggu kelancaran aktivitas pada suatu usaha. Obat merupakan suatu bahan atau campuran bahan yang dipergunakan dalam menentukan diagnosis, mencegah, mengurangi, menghilangkan serta menyembuhkan penyakit atau gejala penyakit [2]. Kebutuhan masyarakat akan obat-obatan sangat besar sejalan dengan meningkatnya permintaan akan obat-obatan pada instalasi farmasi seperti klinik, puskesmas, rumah sakit, apotek dan lain sebagainya. Metode atau cara pengendalian persediaan yang dilakukan selama ini masih belum terlalu optimal untuk dapat memenuhi keseluruhan permintaan obat dari konsumen sehingga mengakibatkan bebrapa permintaan obat tidak dapat terpenuhi. Hal ini dikarenakan permintaan pada beberapa jenis obat seringkali tidak menentu dan justru cenderung bersifat fluktuatif. Hal ini menyebabkan beberapa produk obat habis sebelum pesanan obat baru sampai. Berdasarkan permasalahan tersebut, terdapat potensi perbaikan terhadap sistem pengendalian persediaan obat-obatan pada apotek ini.

Penelitian mengenai pengendalian persediaan obat-obatan sebelumnya pernah dilakukan oleh G.G. Kencana [3] yang melakukan penelitian untuk menentukan kuantitas pemesanan optimum (EOQ) dan reorder point. Selain itu penelitian serupa juga pernah dilakukan oleh A. Bidiawati, S.B. Dyatmika serta T.R. Indarti [4,5,6]. Penelitian pada apotek X kali ini akan lebih berfokus kepada fenomena terjadinya lost sales mengingat apotek ini merupakan apotek yang baru berdiri sehingga reputasi perusahaan untuk memenuhi permintaan konsumen menjadi hal penting yang diutamakan. Maka dari itu, digunakan model persediaan probabilistik Q dengan pertimbangan lost sales. Beberapa penelitian mengenai model ini juga pernah digunakan oleh beberapa peneliti sebelumnya, misalnya pada tulisan yang dibuat oleh D.S Pulungan dan E. Fatma [7]. Tujuan dari penelitian ini diantaranya adalah menentukan jumlah pemesanan yang optimum pada persediaan obat paten kelompok A lost sales berdasarkan model Q Lost Sales, meningkatkan persentase pemenuhan penjualan pada obat paten kelompok A lost sales, melakukan penghematan biaya persediaan pada obat paten kelompok A lost sales.

\section{METODE PENELITIAN}

Penelitian ini diawali dengan melakukan pengamatan secara langsung ke lokasi apotek. Pengamatan dilakukan dengan mengamati aktivitas-aktivitas yang berlangsung dan melakukan wawancara dengan pekerja dan pemilik apotek. Hal ini bertujuan untuk mengetahui semua hal mengenai apotek tersebut baik dalam hal penanganan persediaan pada apotek dan juga jumlah penjualan obat paten setiap bulannya. Langkah selanjutnya adalah melakukan studi literatur untuk mengetahui dasar-dasar penelitian dan metode apa yang tepat untuk mengatasi permasalahan pada apotek tersebut. Setelah itu dilakukan perumusan masalah dan penentuan tujuan penelitian. Pengumpulan data yang dilakukan berupa data permintaan, penjualan, harga obat dan data-data untuk menentukan biaya simpan dan pesan. Langkah awal penentuan permintaan dapat dilihat dari data masa lalu dengan penunjukan pola data deret berkala [8]. Pengolahan data dilakukan dengan terlebih dahulu melakukan pengelompokkan berdasarkan klasifikasi ABC, menentukan obat-obatan kelompok A, melakukan agregasi, forecasting, akurasi, verifikasi dan disagregasi permintaan,menghitung biaya pesan dan simpan, menghitung kuantitas pemesanan optimum dan reorder point serta menentukan total biaya persediaan.

\section{Klasifikasi Jenis Persediaan}

Klasifikasi persediaan berdasarkan pemakaian dan investasi dibagi atas 3 bagian [9], yaitu: (1) persediaan dengan tingkat pemakaian dan investasinya tinggi dengan persen (\%) kumulatifnya $0-70 \%$ yang disebut fast moving dengan, yaitu kategori kelompok A; (2) persediaan dengan tingkat pemakaian dan investasinya sedang dengan persen (\%) 
kumulatifnya 71-90\% yang disebut moderate, yaitu kategori kelompok B; (3) persediaan dengan tingkat pemakaian dan investasinya yang rendah dengan persen (\%) kumulatifnya 91-100\% yang disebut slow moving, yaitu kategori kelompok C.

\section{Peramalan Permintaan Agregat}

Peramalan adalah suatu usaha memperkirakan keadaan di masa yang akan datang melalui pengujian keadaan di masa lalu [10]. Proses agregasi (aggregation) ialah pengelompokan beberapa jenis item menjadi product family. Dalam melakukan peramalan permintaan, seringkali jumlah produk yang diramalkan tidak hanya satu atau dua produk saja namun meliputi bermacam-macam jenis produk sehingga proses agregasi sangat disarankan untuk digunakan dimana beberapa jenis item produk dikonversi menjadi satuan unit agregat yang sama [11].

\section{Verifikasi Hasil Peramalan Permintaan}

Verifikasi dilakukan dengan menggunakan grafik rentang bergerak (moving range chart) untuk membandingkan nilai yang diamati atau data aktual dengan nilai peramalan dari kebutuhan yang sama [12].

\section{Model Probabilistik Q Dengan Pertimbangan Lost Sales dan Reorder Point}

Pengolahan data dilakukan dengan menggunakan Model Q dengan pertimbangan Lost Sales sesuai dengan model matematis Hadley-Within. Pencarian solusi $Q^{*}$ dan $r^{*}$ dengan metode Hadley-Within akan dihitung dengan cara berikut [13]:

1. Hitung nilai $q_{01}{ }^{*}$ awal sama dengan nilai $q_{0 w}{ }^{*}$ dengan formula Wilson

$$
q_{01}^{*}=q_{0 w}^{*}=\sqrt{\frac{2 x D x A}{h}}
$$

2. Berdasarkan nilai $q_{01}{ }^{*}$ yang diperoleh akan dicari besarnya kemungkinan kekurangan inventory $(\alpha) . \mathrm{Z}_{\alpha}$ dapat dicari menggunakan tabel distribusi probabilitas normal.

$$
\propto=\frac{h q_{01}}{C u D+h q_{01}}
$$

Selanjutnya nilai $r_{1}{ }^{*}$ dapat dicari dengan menggunakan persamaan berikut.

$$
r_{1}^{*}=D L+Z_{\alpha} S \sqrt{L}
$$

3. Dengan diketahui $r_{1}{ }^{*}$ yang diperoleh akan dapat dihitung nilai $q_{02}{ }^{*}$ seperti berikut.

$$
q_{02}^{*}=\sqrt{\frac{2 D\left[A+C u \int_{\Gamma}^{\infty}(x-r) f(x) d_{x}\right]}{h}}
$$

Dimana: $N=\int_{\mathrm{r}}^{\infty}(x-r) f(x) d x=S_{L}\left[f\left(Z_{\alpha}\right)-Z_{\alpha} \Psi\left(Z_{\alpha}\right)\right]$

Nilai $\mathrm{f}\left(Z_{\propto}\right)$ dan $\Psi\left(Z_{\alpha}\right)$ dapat dicari dengan pendekatan pada tabel distribusi normal standar

4. Hitung kembali besarnya nilai $\alpha$ (dengan rumus 2) dan nilai $r_{2}{ }^{*}$ menggunakan persamaan berikut:

$$
r_{2}^{*}=D L+Z_{\alpha} S \sqrt{L}
$$

Bandingkan nilai $q o_{1}{ }^{*}$ dan $q o_{2}{ }^{*}$ serta $r_{1}{ }^{*}$ dan $r_{2}{ }^{*}$, jika harga $r_{2}{ }^{*}$ relatif sama dengan $r_{1}{ }^{*}$ iterasi selesai dan akan diperoleh $r^{*}=r_{2}{ }^{*}$ dan $Q^{*}=q o_{2}{ }^{*}$. Jika tidak kembali ke langkah 3 dengan menggantikan nilai $r_{1}{ }^{*}=r_{2}{ }^{*}$ dan $q o_{1}{ }^{*}=q o_{2}{ }^{*}$. 
Keterangan:
$Q^{*} \quad:$ Kuantitas pemesanan optimum
$r \quad$ : Titik pemesanan kembali (Reorder Point)
$N \quad$ : Ekspektasi kekurangan persediaan setiap siklus
$L \quad$ : Waktu ancang-ancang (lead time)
$S \quad$ : Standar deviasi nilai permintaan
$\alpha \quad$ : Probabilitas terjadinya kekurangan persediaan
$\mathrm{f}\left(Z_{\alpha}\right)$ : Fungsi dari nilai z distribusi normal standar untuk $\alpha$
$\Psi\left(Z_{\alpha}\right)$ : Fungi dari nilai z distribusi normal standar untuk $\alpha$ selama lead time
D : Permintaan

\section{Total Biaya Persediaan}

Biaya-biaya persediaan terdiri dari biaya pembelian, biaya pemesanan, biaya penyimpanan serta biaya kekurangan persediaan. Perhitungan ongkos total persediaan menggunakan rumus seperti berikut [14].

$$
O_{T}=D p+\frac{D A}{Q}+h\left(\frac{1}{2} Q+D L\right)+C u \frac{D}{Q} \int_{r}^{\infty}(x-r) f(x) d x
$$

Keterangan:

$O_{T}$ : Ongkos Total Persediaan

$A$ : Harga Pemesanan

$h$ : Harga Simpan

$P \quad$ : Harga Beli Produk Per Unit

$\mathrm{Cu}$ : Harga Kekurangan Persediaan

\section{Two Bin System}

Pada sistem dua bin perusahaan memisahkan persediaan ke dalam dua bagian dimana bagian pertama merupakan tempat persediaan bahan-bahan yang jumlahnya sama dengan jumlah persediaan pada tingkat reorder point dan berfungsi sebagai persediaan cadangan (safety stock) [15]. Pada bagian kedua berisi persediaan yang berjalan dimana persediaan bahan-bahan mula-mula diambil dari bagian kedua sampai habis, dan pada saat bagian kedua ini habis maka menjadi sebuah tanda peringatan (warning sign) bahwa pemesanan kembali harus dilakukan. Pada saat pesanan barang belum diterima, untuk memenuhi kebutuhan maka barang-barang diambil dari bagian pertama sampai barang-barang yang baru dipesan datang di gudang. Apabila barang-barang yang dipesan telah diterima di gudang, maka bagian pertama tempat persediaan cadangan itu diisi lagi terlebih dahulu sampai penuh seperti semula.

\section{HASIL DAN PEMBAHASAN}

Data yang digunakan dalam penelitian ini berupa data permintaan, penjualan, harga obat dan data-data untuk menentukan biaya simpan dan pesan.

\section{Klasifikasi Jenis Persediaan}

Kelompok obat-obatan yang akan diteliti diklasifikasikan terlebih dahulu menggunakan metode klasifikasi ABC. Hasil dari klasifikasi ini digunakan untuk memfokuskan penelitian terhadap produk dengan nilai investasi yang tinggi. Klasifikasi ABC Investasi dapat dilihat pada Gambar 1 di bawah ini. 


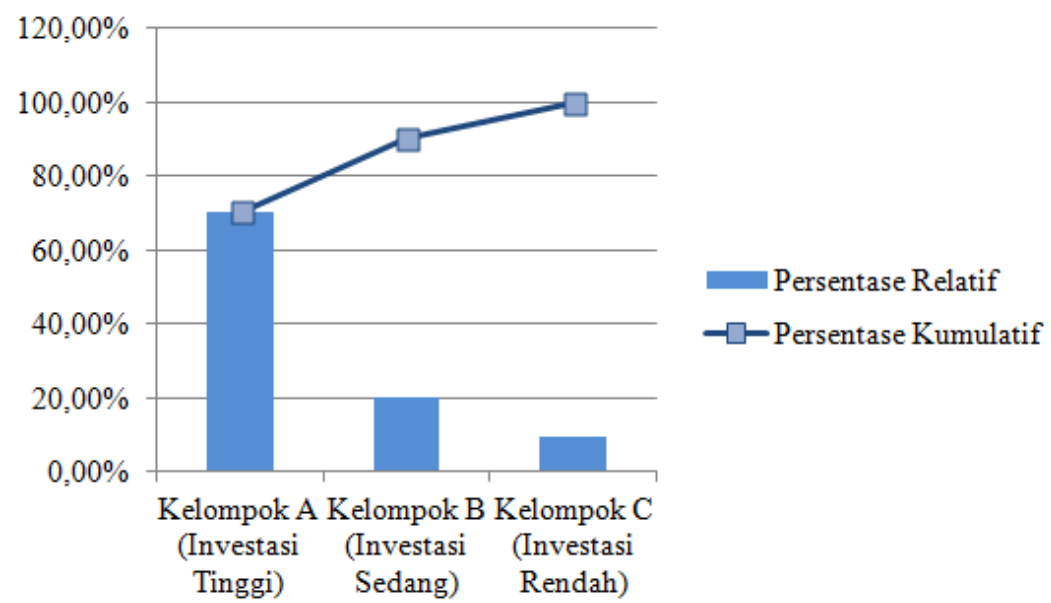

Gambar 1. Diagram Pareto Pengelompokan Obat Paten

\section{Peramalan Permintaan Agregat}

Peramalan permintaan agregat dilakukan dengan melakukan perkalian terhadap jumlah permintaan dan harga jual sebagai unit satuan agregat. Total permintaan agregat dapat dilihat pada Tabel 1 berikut ini.

Tabel 1. Total Permintaan Agregat

\begin{tabular}{ccccccc}
\hline & \multicolumn{5}{c}{ Permintaan Agregat (Rp 1000) } \\
\cline { 2 - 6 } Bulan & Formyco & Mefinal & Sagestam & Sanmol & $\begin{array}{c}\text { Sanmol } \\
\text { Drop }\end{array}$ & $\begin{array}{c}\text { Total } \\
\text { Permintaan }\end{array}$ \\
\hline Mei-18 & 216 & 215,9 & 77,5 & 84 & 160 & 753,4 \\
Jun-18 & 384 & 384,2 & 186 & 336 & 340 & 1630,2 \\
Jul-18 & 288 & 300,9 & 170,5 & 210 & 100 & 1069,4 \\
Agust-18 & 384 & 520,2 & 46,5 & 266 & 520 & 1736,7 \\
Sep-18 & 144 & 419,9 & 108,5 & 126 & 220 & 1018,4 \\
Okt-18 & 336 & 180,2 & 217 & 42 & 120 & 895,2 \\
Nop-18 & 264 & 467,5 & 93 & 364 & 360 & 1548,5 \\
Des-18 & 288 & 282,2 & 170,5 & 238 & 220 & 1198,7 \\
Jan-19 & 120 & 430,1 & 248 & 266 & 340 & 1404,1 \\
Feb-19 & 336 & 323 & 93 & 658 & 500 & 1910 \\
Mar-19 & 240 & 346,8 & 62 & 280 & 240 & 1168,8 \\
Apr-19 & 192 & 309,4 & 186 & 308 & 340 & 1335,4 \\
Mei-19 & 96 & 178,5 & 77,5 & 98 & 60 & 510 \\
Jun-19 & 360 & 249,9 & 232,5 & 210 & 160 & 1212,4 \\
Jul-19 & 72 & 260,1 & 155 & 420 & 320 & 1227,1 \\
Agust-19 & 216 & 329,8 & 186 & 168 & 140 & 1039,8 \\
Sep-19 & 264 & 195,5 & 108,5 & 252 & 220 & 904 \\
\hline Total & $\mathbf{4 2 0 0}$ & $\mathbf{5 3 9 4 , 1}$ & $\mathbf{2 4 1 8}$ & $\mathbf{4 2 7 0}$ & $\mathbf{4 2 8 0}$ & $\mathbf{2 0 5 6 2 , 1}$ \\
\hline Persentase & $\mathbf{1 7 , 5 5 \%}$ & $\mathbf{2 2 , 5 4 \%}$ & $\mathbf{1 0 , 1 1 \%}$ & $\mathbf{1 7 , 8 5 \%}$ & $\mathbf{1 7 , 8 9 \%}$ & $\mathbf{1 0 0 , 0 0 \%}$ \\
\hline
\end{tabular}

Dari data total permintaan agregat pada Tabel 1 di atas, selanjutnya data digambarkan dalam bentuk grafik untuk melihat sebaran pola data berdasarkan permintaan historis. Grafik pola data total permintaan agregat dapat dilihat pada Gambar 2 berikut ini. 


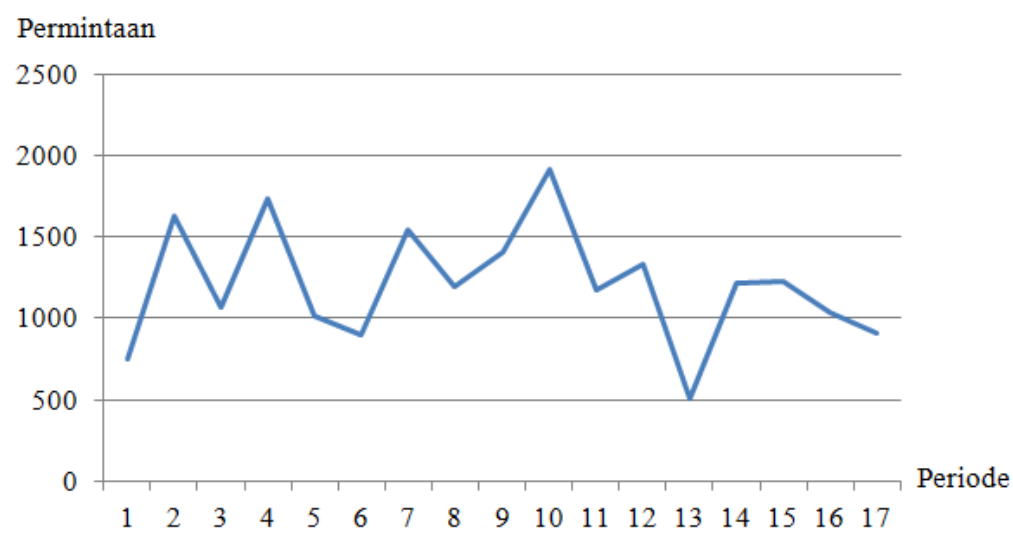

Gambar 2. Grafik Pola Data Total Permintaan Agregat

Berdasarkan pola data permintaan pada Gambar 2, pola data permintaan membentuk pola data horizontal dan trend sehingga untuk menentukan pola data mana yang akan dipakai maka akan dilakukan perhitungan menggunakan software WinQSB. Terdapat 6 metode yang digunakan dimana terdiri dari metode simple average, single moving average dan single exponential smoothing untuk kemunginan pola data horizontal serta metode simple linear regression, double moving average dan double exponential smoothing untuk kemungkinan pola data trend.

\section{Akurasi Peramalan Permintaan}

Rekapitulasi hasil akurasi peramalan untuk permintaan agregat dengan menggunakan metode MAD, MSE dan MAPE dari keenam jenis metode dapat dilihat pada Tabel 2 berikut.

Tabel 2. Akurasi Peramalan Permintaan

\begin{tabular}{clccc}
\hline No. & \multicolumn{1}{c}{ Metode } & MAD & MSE & MAPE \\
\hline 1. & Simple Average & 312,098 & 170.440 & 29,2993 \\
2. & Single Moving Average & 464,638 & $294.531,6$ & 41,9582 \\
3. & Single Exponential Smoothing & 316,461 & $186.008,2$ & 28,9039 \\
4. & Simple Linear Regression & $\mathbf{2 7 5 , 4 4 3}$ & $\mathbf{1 1 8 . 8 3 6 , 3}$ & $\mathbf{2 7 , 1 8 8 1}$ \\
5. & Double Moving Average & 859,94 & 938.043 & 78,2099 \\
6. & Double Exponential Smoothing & 323,434 & $200.809,3$ & 28,957 \\
\hline
\end{tabular}

\section{Verifikasi Hasil Peramalan Permintaan}

Gambar 3 berikut ini menampilkan grafik kendali moving range untuk metode simple linear regression permintaan agregat.

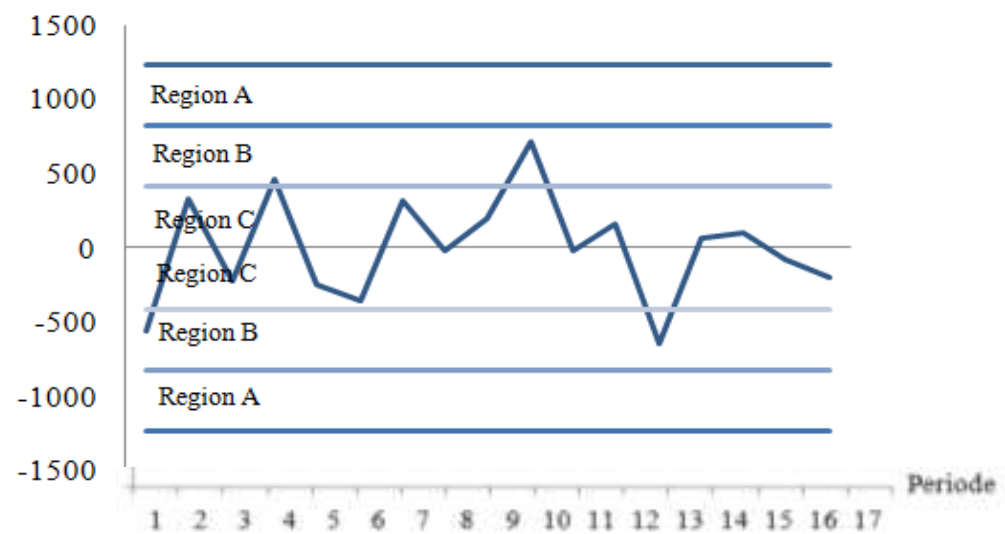

Gambar 3. Grafik Kendali Moving Range Untuk Metode Simple Linear Regression 
Hasil plotting grafik kendali moving range untuk data permintaan agregat selama 17 periode menunjukkan bahwa tidak ada data yang berada di luar batas kontrol. Hal ini karena grafik telah memenuhi keempat syarat yang ada dimana tidak terdapat titik yang berada di luar batas kendali, tidak terdapat 2 titik plot pada region A dari 3 titik yang berurutan, tidak terdapat 4 titik plot pada region B dari 5 titik yang berurutan serta tidak terdapat 8 titik berurutan yang berada pada region $\mathrm{C}$. Karena metode simple linear regression telah dipastikan tidak memiliki data yang out of control, maka hasil peramalan menggunakan metode ini dapat dipastikan menggambarkan permintaan data untuk periode kedepannya.

\section{Disagregasi Hasil Peramalan Permintaan}

Hasil rekapitulasi hasil peramalan permintaan setelah dilakukan disagregasi dapat dilihat pada Tabel 3 di bawah ini.

Tabel 3. Rekapitulasi Hasil Disagregasi Permintaan

\begin{tabular}{cccccc}
\hline & Formyco & Mefinal & Sagestam & Sanmol & $\begin{array}{c}\text { Sanmol } \\
\text { Drop }\end{array}$ \\
\hline November & 7,88 & 142,94 & 7,03 & 13,75 & 9,64 \\
Desember & 7,79 & 141,19 & 6,95 & 13,58 & 9,53 \\
\hline Rata-Rata & $\mathbf{7 , 8 4}$ & $\mathbf{1 4 2 , 0 7}$ & $\mathbf{6 , 9 9}$ & $\mathbf{1 3 , 6 6}$ & $\mathbf{9 , 5 8}$ \\
\hline Standar Deviasi & $\mathbf{0 , 0 6 3 6}$ & $\mathbf{1 , 2 3 7 4}$ & $\mathbf{0 , 0 5 6 6}$ & $\mathbf{0 , 1 2 0 2}$ & $\mathbf{0 , 0 7 7 8}$ \\
\hline
\end{tabular}

\section{Kuantitas Pemesanan Optimum Dengan Model Q Lost Sales dan Reorder Point}

Perhitungan kuantitas pemesanan optimum dilakukan dengan menggunakan model Q Lost Sales. Data masukan yang diperlukan untuk melakukan perhitungan obat Formyco diantaranya biaya pesan sebesar Rp 7.172,-, biaya simpan sebesar Rp 751,-- serta biaya akibat kekurangan persediaan sebesar Rp 3.600,-. Perhitungan nilai Q* dan ROP dilakukan dengan menggunakan persamaan (1),(2),(3),(4),(5) dan (6) sebagai berikut.

a. Hitung nilai $q_{01}{ }^{*}$

$$
\begin{aligned}
& q_{01}{ }^{*}=\sqrt{\frac{2(7,84)(R p 7.172)}{R p 751}} \\
& q_{01}^{*}=12,2392
\end{aligned}
$$

b. Hitung nilai $\alpha$ dan $\mathrm{r}_{1}{ }^{*}$

$$
\begin{aligned}
& \propto=\frac{751(12,2392)}{3.600(7,84)+751(12,2392)} \\
& \propto=0,2456 \\
& r_{1}^{*}=(7,84 \times 0,2)+(-0,6884 \times 0,0636 \times 0,4472) \\
& r_{1}^{*}=1,54842
\end{aligned}
$$

c. Hitung nilai $q_{02}{ }^{*}$

$$
\begin{aligned}
& q_{02}{ }^{*}=\sqrt{\frac{2 \times 7,84[R p 7.172+(R p 3.600 \times 0,0192)]}{R p 751}} \\
& q_{02}{ }^{*}=12,2982
\end{aligned}
$$


d. Hitung kembali nilai $\alpha$ dan nilai $\mathrm{r}_{2}{ }^{*}$.

$$
\begin{aligned}
& \propto=\frac{751(12,2982)}{3.600(7,84)+751(12,2982)} \\
& \propto=0,2465 \\
& r_{2}{ }^{*}=(7,84 \times 0,2)+(-0,6856 \times 0,0636 \times 0,4472) \\
& r_{2}{ }^{*}=1,54850
\end{aligned}
$$

e. Bandingkan $q_{01}{ }^{*}$ dan $q_{02}{ }^{*}(12,2392$ dan 12,2982$)$ serta $r_{1}^{*}$ dan $r_{2}^{*}$ (1,54842 dan 1,54850). Karena nilai $q_{01}{ }^{*}$ dan $q_{02}{ }^{*}$ masih belum signifikan sama, maka dilakukan iterasi berikutnya untuk mendapatkan nilai dari $q_{03}{ }^{*}$ dan $r_{3}{ }^{*}$.

f. Hitung nilai $q_{03}{ }^{*}$

$$
\begin{aligned}
& q_{03}^{*}=\sqrt{\frac{2 \times 7,84[R p 7.172+(R p 3.600 \times 0,0192)]}{R p 751}} \\
& q_{03}{ }^{*}=12,2980
\end{aligned}
$$

g. Hitung kembali nilai $\alpha$ dan nilai $\mathrm{r}_{3}$ dengan menggunakan persamaan berikut.

$$
\begin{aligned}
& \propto=\frac{751(12,2980)}{3.600(7,84)+751(12,2980)} \\
& \propto=0,2465 \\
& r_{3}{ }^{*}=(7,84 \times 0,2)+(-0,6856 \times 0,0636 \times 0,4472) \\
& r_{3}{ }^{*}=1,54850
\end{aligned}
$$

h. Bandingkan $q_{02}{ }^{*}$ dan $q_{03}{ }^{*}(12,2982$ dan 12,2980$)$ serta $r_{2}{ }^{*}$ dan $r_{3}{ }^{*}$ (1,54850 dan 1,54850). Karena nilai dari keduanya sudah signifikan sama, maka diperoleh hasil sebagai berikut.

$$
\begin{array}{ll}
Q^{*} & =q_{03}{ }^{*}=12,2980 \approx 13 \text { unit } \\
\text { ROP } & =r_{3}{ }^{*}=1,54850 \approx 2 \text { unit }
\end{array}
$$

Rekapitulasi hasil perhitungan Model Q dengan Lost Sales dan reorder point sesuai dengan model matematis Hadley-Within dapat dilihat pada Tabel 4 di bawah ini.

Tabel 4. Rekapitulasi Kuantitas Pemesanan dan Reorder Point

\begin{tabular}{clcc}
\hline No. & \multicolumn{1}{c}{ Nama Obat } & Q* $^{*}$ & ROP \\
\hline 1. & Formyco 2\% Cream 10 g & 13 & 2 \\
2. & Mefinal 500 mg & 43 & 29 \\
3. & Sagestam 0,1\% 10 g & 12 & 2 \\
4. & Sanmol Sirup 60 ml & 12 & 3 \\
5. & Sanmol Drop 15 ml & 10 & 2 \\
\hline
\end{tabular}

Pemilihan model Q ini dilakukan karena permintaan bersifat fluktuatif sehingga pemesanan akan lebih baik apabila dilakukan berdasarkan jumlah persediaan. Model persediaan probabilistik $\mathrm{Q}$ ini menggunakan langkah iteratif untuk mendapatkan nilai $\mathrm{Q}$ dan ROP yang optimum. Hasil perhitungan dengan menggunakan model Q ini untuk obat Formyco Cream 2\% 10 g harus melewati tiga kali langkah iterasi. Hal ini dikarenakan pada iterasi kedua nilai dari $q_{01}{ }^{*}$ dan $q_{02}{ }^{*}(12,2392$ dan 12,2982$)$ belum signifikan sama karena pada penelitian ini kedua parameter dikategorikan signifikan sama apabila angkanya telah sama persis hingga 2 angka desimal dibelakang koma. Langkah iterasi ketiga untuk obat Formyco Cream 2\% $10 \mathrm{~g}$ menghasilkan nilai Q optimum sebesar 13 unit dengan nilai ROP sebesar 2 unit. 


\section{Total Biaya Persediaan}

Perhitungan total biaya persediaan dilakukan terhadap biaya persediaan hasil teoritis, sebelum implementasi dan setelah implementasi.

Tabel 5. Rekapitulasi Hasil Perhitungan Biaya Persediaan

\begin{tabular}{clccc}
\hline No. & \multicolumn{1}{c}{ Nama Obat } & $\begin{array}{c}\text { Perhitungan } \\
\text { Teoritis (Rp) }\end{array}$ & $\begin{array}{c}\text { Sebelum } \\
\text { Implementasi (Rp) }\end{array}$ & $\begin{array}{c}\text { Setelah } \\
\text { Implementasi (Rp) }\end{array}$ \\
\hline 1. & Formyco 2\% Cream 10 g & 167.191 & 261.177 & 160.146 \\
2. & Mefinal 500 mg & 286.586 & 448.922 & 327.469 \\
3. & Sagestam 0,1\% 10 g & 101.834 & 212.205 & 115.889 \\
4. & Sanmol Sirup $60 \mathrm{ml}$ & 183.525 & 307.095 & 187.815 \\
5. & Sanmol Drop $15 \mathrm{ml}$ & 179.879 & 245.426 & 214.406 \\
\hline \multicolumn{6}{c}{ Total } & $\mathbf{9 1 9 . 0 1 4}$ & $\mathbf{1 . 4 7 4 . 8 2 5}$ & $\mathbf{1 . 0 0 5 . 7 2 5}$ \\
\hline
\end{tabular}

Total biaya hasil perhitungan secara teoritis untuk kelima jenis obat paten kelompok A lost sales sebesar Rp 919.014,-- Hasil perhitungan ini jauh lebih rendah apabila dibandingkan dengan total biaya persediaan yang diterapkan oleh pihak apotek selama dua bulan terakhir yakni sebesar Rp 1.478.825,-. Hal ini dikarenakan pada total biaya persediaan secara teoritis besarnya perkiraan jumlah produk stockout hanya berada dikisaran 0 hingga 0,2 sehingga salah satu faktor yang ada pada total biaya persediaan yakni biaya stockout menjadi jauh berkurang (lebih kecil). Selain itu, hasil teoritis ini juga dilakukan dengan menggunakan perhitungan dari model persediaan probabilistik $\mathrm{Q}$ dengan pertimbangan lost sales sehingga fokus utama dari model ini adalah memperkecil kemungkinan untuk terjadinya lost sales serta pemesanan barang dilakukan dengan jumlah paling optimum sehingga biaya persediaan yang dikeluarkan menjadi jaiuh lebih kecil. Total biaya secara keseluruhan untuk hasil implementasi sebesar Rp 1.005.725,--. Apabila dibandingkan dengan total biaya keseluruhan secara teoritis, maka terdapat perbedaan sebesar Rp 86.711,-. Perbedaan hasil perhitungan ini disebabkan karena jumlah permintaan hasil peramalan tidak sama persis dengan jumlah permintaan pada sistem nyata. Perbedaan permintaan hasil ramalan dan sistem nyata ini disebabkan data jumlah permintaan secara historis yang tidak diketahui secara pasti. Selain itu, faktor kekosongan stok obat yang terjadi pada obat Mefinal juga menyebabkan total biaya persediaan menjadi bertambah diakibatkan faktor dari biaya pinalti akibat terjadinya lost sales. Namun jumlah peramalan ini telah mendekati jumlah permintaan yang terjadi pada sistem nyata sehingga perbedaan total biaya keseluruhan tidak begitu besar yakni hanya $\mathrm{Rp} 86.711,-$.

Selanjutnya penghematan biaya persediaan didapatkan dengan membandingkan biaya persediaan setelah implementasi terhadap sebelum implementasi.

Tabel 6. Penghematan Biaya Persediaan

\begin{tabular}{|c|c|c|c|c|c|}
\hline No. & Nama Obat & $\begin{array}{c}\text { Total Biaya } \\
\text { Awal (Rp) }\end{array}$ & $\begin{array}{l}\text { Total Biaya } \\
\text { Akhir (Rp) }\end{array}$ & $\begin{array}{c}\text { Penghematan } \\
\text { Biaya (Rp) }\end{array}$ & Persentase \\
\hline 1. & Formyco $2 \%$ Cream $10 \mathrm{~g}$ & 261.177 & 160.146 & 100.761 & $38,58 \%$ \\
\hline 2. & Mefinal $500 \mathrm{mg}$ & 448.922 & 327.469 & 121.453 & $27,05 \%$ \\
\hline 3. & Sagestam $0,1 \% 10 \mathrm{~g}$ & 212.205 & 115.889 & 96.316 & $45,39 \%$ \\
\hline 4. & Sanmol Sirup $60 \mathrm{ml}$ & 307.095 & 187.815 & 119.280 & $38,84 \%$ \\
\hline 5. & Sanmol Drop $15 \mathrm{ml}$ & 245.426 & 214.406 & 31.020 & $12,64 \%$ \\
\hline & Total & $\mathbf{1 . 4 7 4 . 8 2 5}$ & $\mathbf{1 . 0 0 5 . 7 2 5}$ & 468.830 & $31,79 \%$ \\
\hline
\end{tabular}

Perbandingan perhitungan total biaya sebelum implementasi dan setelah implementasi menunjukkan hasil yang cukup signifikan. Berdasarkan hasil perhitungan total biaya yang dikeluarkan oleh perusahaan sebelum implementasi perusahaan mengeluarkan total dana sebesar Rp 1.474.825,-- sedangkan setelah dilakukan implementasi hasil penelitian, maka total biaya secara keseluruhan menurun menjadi Rp 1.005.725,-. Hal 
ini menunjukan bahwa melalui hasil implementasi yang dilakukan selama dua bulan terakhir maka terjadi penghematan total biaya persediaan sebesar Rp 468.830,- atau sebesar $31,79 \%$. Penghematan biaya persediaan ini terjadi karena setelah dilakukan implementasi sistem persediaan dua bin dan aplikasi model persediaan probabilistik Q dengan pertimbangan lost sales, maka jumlah permintaan konsumen yang dapat dipenuhi menjadi bertambah serta jumlah permintaan yang tidak dapat dipenuhi (lost sales) menjadi berkurang sehingga total biaya persediaan yang diperlukan menjadi lebih sedikit.

\section{KESIMPULAN}

Berdasarkan hasil perhitungan jumlah pemesanan yang optimum berdasarkan model persediaan probabilistik Q dengan pertimbangan Lost Sales yakni sebanyak 13 unit obat Formyco Cream 2\% $10 \mathrm{~g}, 43$ unit obat Mefinal $500 \mathrm{mg}, 12$ unit obat Sagestam 0,1\% $10 \mathrm{~g}$, 12 unit obat Sanmol Sirup $60 \mathrm{ml}$ serta 10 unit Sanmol Drop $15 \mathrm{ml}$. Selain itu dengan melakukan pemesanan sejumlah kuantitas optimum berdasarkan model persediaan probabilistik Q dengan pertimbangan Lost Sales pada obat paten kelompok A lost sales selama dua bulan terakhir, maka terjadi peningkatan persentase pemenuhan jumlah pemenuhan permintaan dibandingkan dengan dua bulan sebelumnya yakni $4,55 \%$ untuk obat Formyco Cream 2\% $10 \mathrm{~g} ; 12,65 \%$ untuk obat Mefinal $500 \mathrm{mg} ; 43,45 \%$ untuk obat Sagestam 0,1\% $10 \mathrm{~g}, 16,67 \%$ untuk obat Sanmol Sirup $60 \mathrm{ml}$ serta 41,57\% unit Sanmol Drop $15 \mathrm{ml}$ atau sebesar 23,78\% secara rata-rata untuk kelima jenis obat tersebut. Dari segi pengematan biaya, terjadi penghematan biaya persediaan untuk kelima jenis obat paten kelompok A lost sales adalah sebesar Rp 468.830,- atau sebesar 31,79\% dari total biaya persediaan semula. Keterbatasan pada penelitian ini berupa seluruh hasil perhitungan yang masih dikerjakan secara manual sehingga akan sangat merepotkan apabila ingin menerapkan metode ini untuk menghitung kuantitas pemensanan item dengan jumlah yang sangat banyak. Di kemudian hari, akan lebih baik apabila dapat dibuat software dengan menggunakan algoritma dari model probabilistik Q dengan pertimbangan lost sales ini.

\section{DAFTAR PUSTAKA}

[1] E. Herjanto, Manajemen Produksi dan Operasi. Jakarta : Gramedia Widiasarana Indonesia, 2003.

[2] M. Anief, Apa Yang Perlu Diketahui Tentang Obat. Yogyakarta : Gadjah Mada University Press, 1991.

[3] G.G. Kencana, "Analisis Perencanaan dan Pengendalian Persediaan Obat Antibiotik di RSUD Cicalengka Tahun 2014," Jurnal ARSI, vol. 3, no. 1, pp. 42-52, Okt. 2016.

[4] A. Bidiawati, "Sistem Persediaan Obat-Obatan Menggunakan Metode Periodic Review dan Service Level Di Instalasi Farmasi Rumah Sakit," Jurnal Teknos-2k, vol. 6, no. 2, pp 45-54, Jul. 2006.

[5] S.B. Dyatmika, "Pengendalian Persediaan Obat Generik Dengan Metode Analisis ABC, Metode Economic Order Quantity (EOQ), Dan Reorder Point (ROP) Di Apotek XYZ Tahun 2017," MODUS, vol. 30, no.1, pp. 87-95, 2018.

[6] T.R. Indarti, "Pengendalian Persediaan Obat dengan Minimum Maximum Stock Level di Instalasi Farmasi RSUP Dr. Sardjito Yogyakarta," JMPF, vol. 9, no. 3, pp. 192-202, 2019.

[7] D.S Pulungan dan E. Fatma, "Analisis Pengendalian Persediaan Menggunakan Metode Probabilistik dengan Kebijakan Backorder dan Lost Sales," JTIUMM, vol. 19, no. 1, pp. 28-38, Feb. 2018.

[8] J. Chandra dan T. Sunarni, "Perancangan Tata Letak Mi Instan di Toko Amuk dengan Mempertimbangkan Sistem Persediaan," Jurnal Ilmiah Teknik Industri, vol. 7, no. 1, pp. 60-69, 2019. 
[9] Dirjen Binakefarmasian dan Alat Kesehatan Kemenkes RI, Pedoman Pengelolaan Perbekalan Farmasi. Jakarta : Bakti Husada, 2010.

[10] F.A. Reicita, "Analisis Perencanaan Produksi pada PT. Armstrong Industri Indonesia dengan Metode Forecasting dan Agregat Planning," Jurnal Ilmiah Teknik Industri, vol. 7, no. 3, pp. 160-168, 2019.

[11] H. Kusuma, Manajemen Produksi Perencanaan dan Pengendalian Produksi. Yogyakarta : Andi Offset, 2009.

[12] P.N. Eris, "Peramalan Dengan Metode Smoothing dan Verifikasi Metode Peramalan Dengan Grafik Pengendali Moving Range (MR)," Jurnal Eksponenisal, vol 5, no. 2, pp. 203-210, Nop. 2014.

[13] S.N. Bahagia, Sistem Inventori. Bandung : Departemen Teknik Industri ITB, 2006.

[14] Azriza, "Optimalisasi Persediaan Suku Cadang Bearing Mesin Produksi," Skripsi, UIN Sultan Syarif Kasim, Riau, 2011.

[15] S, Assauri, Manajemen Produksi dan Operasi. Jakarta : Universitas Indonesia, 2004. 